\title{
PENERAPAN GCG PADA BANK UMUM SYARIAH DI INDONESIA
}

\author{
Zul Ihsan Mu'arrif \\ Universitas Islam Negeri Sunan Kalijaga
}

Email: zihsan14@gmail.com

\begin{abstract}
This study aims to see how far the application of GCG in Islamic banking in Indonesia. Because the Sharia Bank is a bank whose application of activities is different from conventional banks. Where one of the differences is the existence of a Sharia Supervisory Board that ensures the activities of banks based on sharia. Then a study of Islamic banks was conducted during 2014 until 2018. The method used was ANOVA and Panel Data Regression. The research results show that in the average test it was found that the application of GCG to Islamic banks was 'good', not yet able to reach the 'very good' level. In the panel test a number of points were found. First in general testing, the Board of Commissioners and Directors significantly influence GCG, while the Sharia Supervisory Board does not show significant results. In testing the fixed effect it was found that the Board of Directors and the Board of Commissioners were not significant indicating that both the Board of Directors and the Board of Commissioners had similarities in their various decisions. While the Sharia Supervisory Board showed significant results which meant that DPS had differences in their decisions. In the results of the time analysis it was found that the implementation of the GCG function did not change from time to time. It was found that the influence of individual banks was significant, while the influence of individual years was not significant.
\end{abstract}

Keywords: GCG, sharia bank, board of commissioners, directors, sharia supervisory board

\begin{abstract}
Abstrak
Penelitian ini bertujuan untuk melihat sejauh apa penerapan GCG pada perbankan syariah di Indonesia. Karena Bank Syariah merupakan bank yang penerapan aktivitas kegiatannya berbeda dengan bank konvensional. Dimana salah satu perbedaannya adalah adanya Dewan Pengawas Syariah yang memastikan akivitas bank berdasarkan syariah. Maka dilakukan penelitian terhadap bank-bank syariah selama tahun 2014 sampai 2018. Metode yang digunakan adalah ANOVA dan Regresi Data Panel. Hasil penellitan menunjukkan bahwa dalam uji rata-rata didapati bahwa penerapan GCG pada bank syariah adalah 'bagus', belum bisa sampai pada tingkat 'sangat bagus'. Dalam uji panel didapati beberapa poin. Pertama dalam pengujian secara
\end{abstract}


umum, Dewan Komisaris dan Direksi secara signifikan mempengaruhi GCG, sedangkan Dewan Pengawas Syariah tidak menunjukkan hasil yang signifikan. Dalam pengujian fixed effect didapati bahwa Direksi dan Dewan Komisaris tidak signifikan yang menunjukkan bahwa baik Direksi maupun Dewan Komisaris memiliki kesamaan dalam berbagai keputusan mereka. Sedangkan Dewan Pengawas Syariah menunjukkan hasil yang signifikan yang berarti DPS memiliki perbedaan dalam keputusan mereka. Dalam hasil analisis waktu didapati bahwa peneranan fungsi GCG tidak mengalami perubahan dari waktu ke waktu. Didapati bahwa pengaruh individu bank signifikan, sedangkan pengaruh individu tahun tidak signifikan.

Kata kunci: : GCG, bank syariah, dewan komisaris, direksi, dewan pengawas syariah.

\section{A. PENDAHULUAN}

Pengendalian perusahaan menjadi isu yang sangat serius yang dihadapi oleh berbagai pihak. Hal ini dilakukan agar terciptanya independensi bagi manajer dalam menghasilkan kinerja perusahaan yang maksimal. Pengelolaan perusahaan oleh para profesional dilakukan secara terpisah antara pihak-pihak yang berkepentingan. Sehingga terdapat fungsi kontrol antar organ-organ perusahaan (RUPS, Direksi, dan Dewan Komisaris). Selain independensi, prinsip keterbukaan juga menjadi penting dalam menciptakan lingkungan bisnis yang sehat. Transparansi dilakukan untuk menjaga keseimbangan kepentingan antara pemegang saham dengan manajemen. Karena dengan adanya transparansi, pemegang saham akan dapat menilai bagaimana kinerja perusahaan yang di Investasikan dengan melihat bagaimana kinerja laporan keuangan.

Hubungan antara pihak pengambil keputusan dengan manajemen didasarkan dari asumsi bahwa manajemen melakukan tindakan berdasarkan kepentingannya dengan mengorbankan kepentingan pemegang saham (agency theory). Konflik agensi yang timbul disebabkan oleh berbagai hal (Alijoyo \& Zaini, 2004), seperti Moral-Hazard, Earning Retention, Risk Aversion, dan Time-Horizon. Asumsi ini dibangun untuk mencegah terjadinya kesenjangan antara pemegang saham dengan 
manajemen, dimana pemilik memiliki kepentingan untuk mendapatkan return yang maksimal, sedangkan manajer memiliki kepentingan terhadap insentif atas pengelolaan dana.

Sistem corporate governance dibangun untuk mengatur kewenangan direksi agar tidak menyalahgunakan kewenangan dan memastikan untuk bekerja hanya untuk kepentingan perusahaan. Corporate governance dilakukan untuk memonitor pengurus perseroan dalam berbagai industri, seperti perbankan, pasar modal, dan perusahaan lainnya. Aturan-aturan corporate governance bukan sekedar memperhatikan bagaimana jalannya bisnis perusahaan, tetapi juga tentang pengawasan dan kontrol perusahaan secara keseluruhan termasuk kebijakan direksi. Sehingga didalam corporate governance harus meliputi empat prinsip agar berjalan dengan benar (Surya \& Yustiavanda, 2006), yaitu Direction, Executive action, Pengawasan, dan Akuntabilitas. Empat prinsip ini merupakan poin penting bagi perusahaan dengan harapan akan adanya kepatuhan perusahaan terhadap regulasi dan meminimalisir kesenjangan.

Perusahaan yang mempraktikkan tatakelola yang baik menunjukkan bahwa fungsi pemantauan anggota dewan yang meningkat (Shahid \& Abbas, 2019). Sehingga mengakibatkan keputusan manajer yang efektif dan kinerja yang lebih meningkat (Ben Slimane \& Padilla Angulo, 2018). Efektifitas ini menandakan perilaku oportunistik manajer yang berkurang dalam memanipulasi laba yang akan dilaporkan (Nazir \& Afza, 2018), karena kecenderungan manajer terhadap pengelolaan laporan keuangan yang oportunistik. Bahkan beberapa perusahaan yang dikelola dengan baik menunjukkan tingkat risiko gagal bayar yang lebih rendah (Ali, Liu, \& Su, 2018). Secara keseluruhan praktik tata kelola perusahaan itu sendiri mempengaruhi kinerja perusahaan (Pillai \& Al-Malkawi, 2018). Implikasinya menimbulkan keterpaduan antara manajer dan pemegang 
saham dalam menjalankan bisnisnya yang efektif sesuai dengan peraturan pedoman ketatakelolaan.

Implementasian good corporate governance di Indonesia juga dimulai dengan penandatanganan nota kesepatakan antara Indonesia dan IMF dengan terbentuknya Komite Nasional Kebijakan Corporate Governance (KNKCG) yang merumuskan pedoman bagi permasalahan GCG di Indonesia yang akan dilaksanakan oleh perusahaan yang beroperasi di Indonesia. Pada tanggal 29 November 2000 diresmikan pedoman berdasarkan keputusan Menko Perekonomian no. 31/M.Ekuin/06/2000, yang merekomendasikan perbaikan atas aturan-aturan implementasian pedoman tersebut.

Pada dasarnya prinsip GCG merupakan sebuah pilihan dalam menjalankan kegiatan ekonomi. Namun, prinsip tersebut menciptakan tata kelola yang baik dan meningkatkan value pada perusahaan tersebut. Melihat pentingnya penerapan GCG, diperlukan peranan institusi publik sebagai regulator yang menjadi tolak ukur GCG seperti pengadilan, Badan Pengawasan Pasar Modal, Bank Indonesia, maupun lembaga lainnya (Surya \& Yustiavanda, 2006). Prinsip ini seharusnya dilakukan oleh Perseroan Terbatas, BUMN, Lembaga Perbankan, dan lembaga lainnya yang memang dibutuhkannya tatakelola perusahaan yang baik.

Intstitusi perbankan sendiri telah melaksanakan prinsip GCG tertanggal 30 Januari 2006 yang diatur pada peraturan Bank Indonesia no.8/4/PBI/2006. Dimana peraturan ini bertujuan untuk memperkuat kondisi perbankan dalam menghadapi risiko, melindungi kepentingan stakeholders, serta meningkatkan kepatuhan terhadap perundang-undangan yang berlaku dalam industri perbankan.

Terkait dengan risiko yang dihadapi bank, bahwa bank menghadapi risiko kredit (baik dalam pembiayaan maupun dalam bentuk utang) yang tergantung dari sistem pengelolaannya. Dimana di Indonesia terdapat dua 
sistem perbankan yang berbeda sehingga risiko yang dihadapinya juga berbeda. Bank syariah dalam mengelola risiko lebih baik daripada bank konvensional (Hassan, Khan, \& Paltrinieri, 2019), terlebih ketika krisis keuangan global yang membuat bank syariah lebih efisien daripada bank konvensional (Asmild, Kronborg, Mahbub, \& Matthews, 2018), juga efisiensi biaya yang lebih baik daripada bank konvensional (Alqahtani, Mayes, \& Brown, 2017). Memang, setelah periode krisis, perkembangan bank syariah semakin meningkat dengan beberapa pembuktian bahwa bank syariah tahan terhadap krisis keuangan, bahkan pembiayaan bank syariah mengalami peningkatan dari pada pinjaman bank konvensional (Ibrahim \& Rizvi, 2018). Bahkan bank syariah lebih menguntungkan daripada bank konvensional berdasarkan laporan keuangan bank (Ramlan \& Adnan, 2016). Dalam analisis lain juga menunjukkan bahwa bank syariah lebih tangguh daripada bank konvensional, terlihat dari volatilitas yang tinggi pada bank konvensional (Fakhfekh, Hachicha, Jawadi, Selmi, \& Idi Cheffou, 2016).

Namun, fakta lain menunjukkan bahwa kinerja biaya dan laba bank syariah lebih buruk dari bank konvensional (Alexakis, Izzeldin, Johnes, \& Pappas, 2019). Memang selama krisis, bank syariah tahan terhadap goncangan, tetapi selama akhir periode krisis, ketidakstabilan keuangan bank syariah lebih tinggi dari pada bank konvensional (Alqahtani \& Mayes, 2018) ditambah dengan kinerja yang lebih buruk dengan penurunan permodalan, profitabilitas, dan efisiensi (Alqahtani, Mayes, \& Brown, 2017) (Olson \& Zoubi, 2017). Disisi lain, terdapat perbedaan efisiensi antara kedua bank yang menunjukkan bank konvensional lebih efisien daripada bank syariah (Abdul-Majid, Falahaty, \& Jusoh, 2017). Artinya bahwa bank konvensional lebih efisien dalam mengelola biaya daripada bank syariah (Miah \& Uddin, 2017). Tingkat kegagalan bank syariah juga lebih tinggi daripada bank konvensional (Alandejani, Kutan, \& Samargandi, 2017), 
yang menandakan bahwa ketahanan bank syariah belum stabil sehingga keberlangsungan bank syariah yang lebih singkat. Permasalahan keagenan juga terlihat bahwa bank konvensional relatif lebih kurang dan kecenderungan bank syariah yang memiliki permasalahan keagenan (Athari, Adaoglu, \& Bektas, 2016).

Melihat fenomena diatas, bahwa disatu sisi, bank syariah lebih bagus

dari bank konvensional, namun disisi lain sebaliknya. Perlu dilihat bagaimana praktik penerapan GCG pada bank syariah, dimana praktik tata kelola perusahaan dapat meningkatkan kinerja perusahaan (Patel, Guedes, Soares, \& da Conceição Gonçalves, 2018) yang pada akhirnya mempengaruhi nilai perusahaan (Nazir \& Afza, 2018).

Penelitian ini berbeda dari penelitian sebelumnya yang melihat pengaruh penerapan GCG pada bank syariah. Penelitian ini ingin melihat bagaimana penerapan GCG itu sendiri pada Bank Umum Syariah di Indonesia. Memang pada saat krisis keuangan, bank syariah memiliki ketahanan dari pada bank konvensional, akan tetapi dari beberapa penelitian menunjukkan bahwa bank syariah setelah krisis keuangan menunjukkan kinerja yang rendah daripada bank konvensional. Beberapa penyebab bisa mempengaruhi penurunan kualitas bank syariah, salah satunya bagaimana penerapan tata kelola perusahaan pada bank syariah itu sendiri.

\section{B. TINJAUAN PUSTAKA}

Corporate Governance merupakan suatu sistem yang dilakukan guna mencapai keseimbangan perusahaan sebagai keberlangsungan eksistensinya, dimana pada prinsipnya terdapat beberapa aspek yang universal yang terdapat dalam masing-masing pedoman, yaitu Corporate Objective, Voting Right, Non-executive Corporate Board, Corporate Remuneration Policies, Strategic Focus, Operating Performance, Shareholders Returns, dan 
Corporate Citizenship (Alijoyo \& Zaini, 2004). Maka, pedoman yang ada pada suatu negara harus diterapkan oleh perusahaan pada negara yang bersangkutan. Karena prinsip ini menjadi sangat penting agar mencegah praktik ketimpangan yang akan terjadi.

Dalam lingkup bank, GCG menerapkan prinsip keterbukaan (transparency), akuntabilitas (accountability), pertanggungjawaban (responsibility), independensi (independency), dan kewajaran (fairness) (Effendi, 2016), yang dalam pelaksanaannya menjalankan fungsi pengendalian internal, penerapan fungsi kepatuhan, auditor internal dan eksternal, penerapan manajemen risiko, serta transparansi kondisi keuangan bank.

Penerapan tata kelola perusahaan ini mendorong perusahaan untuk mempraktikkan tata kelola perusahaan yang baik. Dimana didalam tata kelola yang terdiri dari lima aspek tersebut mencakup delapan prinsip tata kelola perusahaan yang baik serta 25 rekomendasi penerapan aspek tata kelola perusahaan ${ }^{1}$. Aturan ini juga mencakup pedoman bagi pemegang saham, Dewan komisaris, Direksi, Dewan Pengawas Syariah, dan komite lainnya yang terdapat pada struktur perbankan. Penilaian akan dilakukan kepada masing-masing pejabat, seperti bagaimana penyelenggaraan rapat pada setiap kabinetnya, bagaimana komunikasi perusahaan dengan pemegang saham atau investor, memperjelas fungsi dan peran dewan komisaris, bagaimana seharusnya kualitas pelaksanaan tugas direksi, bagaimana partisipasi pemangku kepentingan, dan keterbukaan informasi. Sehingga fungsi pengawasan tergambar jelas dengan berbagai penilaian terhadap pihak yang mengambil keputusan. Prinsip-prinsip GCG ini harus dilakukan secara terus menerus agar interaksi pada seluruh organ

1 Berdasarkan setiap laporan tata kelola perusahaan, dimana setiap perusahaan menampilkan pedoman GCG setiap tahunnya, dalam hal ini bersumber dari laporan GCG bank Muamalat tahun 2018 
perusahaan menjadi maksimal berdasarkan peraturan perundangundangan dan anggaran dasar

Permasalah perbankan yang sangat kompleks dikarenakan berbagai risiko yang dihadapi, maka kebutuhan akan praktik tata kelola perusahaan yang baik (good corporate governance) sangat dibutuhkan. Mengingat bahwa perbankan mengelola dana publik yang rentan akan berbagai kendala. Berdasarkan peraturan yang telah dibuat, diharapkan dapat meminimalisir penyimpangan baik yang dilakukan oleh direksi, maupun pemegang saham. Dimana peraturan tersebut bertujuan untuk meningkatkan kinerja perbankan menjadi lebih baik dan sehat. Untuk itu perbankan perlu dikelola oleh orang-orang yang memiliki kompetensi dan integritas yang tinggi dalam memenuhi persyaratan perundang-undangan.

Transparansi dibutuhkan untuk memperjelas manfaat dan risiko pada produk dan meningkatkan perlindungan terhadap nasabah. Hal ini dilakukan untuk mengurangi asimetri informasi akan kewajiban bank dalam menyampaikan informasi kepada nasabah agar tidak adanya penyesatan serta penyebarluasan data pribadi nasabah. Dalam meningkatkan transparansi, Bank Indonesia mengedarkan surat kepada seluruh bank umum di Indonesia dengan no.15/15/DPNP pada tanggal 29 April, serta peraturan Otoritas Jasa Keuangan (OJK) no.6/POJK.03/2015 tanggal 31 Maret 2015 tentang transparansi dan publikasi laporan bank (Effendi, 2016). Peraturan ini dilakukan agar kondisi keuangan dan kinerja bank menjadi lebih sehat dan meningkatkan kepercayaan nasabah serta investor dikarenakan penyampaian informasi keuangan yang tidak diragukanlagi.

Prinsip transparansi ini sangat penting bagi publik dalam pengambilan keputusan berdasarkan informasi yang relevan terkait kondisi perusahaan. Perusahaan akan memberikan laporan tahunan yang didalamnya merupakan fundamental perusahaan. Berdasarkan PP no. 24 
tahun 1998 (Effendi, 2016), bahwa transparansi keuangan menciptakan efisiensi dan peningkatan daya saing. Dimana perusahaan wajib menyampaikan laporan keuangan perusahaan, karena nasabah membutuhkan keterbukaan informasi. Perbankan itu sendiri merupakan lembaga keuangan yang mengelola dana masyarakat, maka sudah seharusnya pihak perbankan memberikan informasi yang relevan, akurat, seimbang, dan terus menerus. Informasi yang dibutuhkan terutama dalam risiko operasional, karena informasi ini merupakan nilai yang relevan digunakan oleh investor sebagai informasi tambahan penilaian risiko bank (Neifar \& Jarboui, 2018)

Pengawasan pada perbankan juga berperan dalam komite audit. Sehingga OJK harus melakukan pengawasan terhadap pengelola bank agar tidak adanya konflik kepentingan yang dapat merugikan berbagai pihak. Penyaringan dilakukan dengan melihat track record dewan, apakah pernah melakukan perbuatan pelanggaran hukum maupun pencegahan akan adanya perangkapan jabatan yang dapat mengurangi fungsi dari dewan itu sendiri. Restrukturisasi juga diperlukan guna peningkatan kinerja dan efisiensi perusahaan (Ben Slimane \& Padilla Angulo, 2018).

Transparansi keuangan merupakan bentuk pengawasan yang baik bagi perusahaan. sebagai implikasi dari praktik GCG yang dilakukan. Pada akhirnya perusahaan yang menjalankan GCG dengan baik, akan terus bertahan dengan siklus hidup yang cukup lama sebagai dampak dari adanya pengungkapan perusahaan, investasi, pendanaan, dan tanggung jawab secara sosial (Habib \& Hasan, 2019) seperti peningkatan CSR oleh manajer (Ducassy \& Montandrau, 2015), yang secara tidak langsung meningkatkan nilai perusahaan dalam industri yang kompetitif $(\mathrm{Yu}, \mathrm{Li}, \&$ Yang, 2017). Karena antara tata kelola perusahaan dan nilai perusahaan terdapat hubungan yang positif (Connelly, Limpaphayom, Nguyen, \& Tran, 2017). Artinya semakin baik tata kelola perusahaan, semakin 
meningkat nilai perusahaan itu didalam pasar. Dampak lain yang ditimbulkan dari mekanisme tata kelola perusahaan yang efektif yaitu kebijakan yang tidak melanggar hukum (Li, Li, Liu, Wang, \& Wu, 2017). Serta membatasi pengambilan risiko yang berlebihan (Iqbal, Strobl, \& Vähämaa, 2015). Dimana hal ini menjadi penting dalam membangun kondisi perekonomian yang stabil. Agar tidak terjadi krisis yang dapat merugikan semua kalangan dalam sebuah negara.

Bank Islam yang notabenenya merupakan perbankan yang menerapkan prinsip-prinsip syariah sudah seharusnya fungsi tata kelola yang baik menjadi sebuah kebutuhan perusahaan, karena sejalan dengan nilai-nilai keislaman, seperti tabligh yang artinya menyampaikan apa yang seharusnya. Ditambah lagi bahwa didalam perbankan syariah itu sendiri terdapat Dewan Pengawas Syariah yang tidak dimiliki oleh perbankan konvensional. Dimana fungsi dari Dewan Pengawas Syariah mengawasi penerapan pemenuhan prinsip syariah dalam kegiatan perbankan yang dibuktikan dengan penyampaian laporan pengawasan dalam kurun waktu tertentu kepada DSN-MUI dan Otoritas Jasa Keuangan.

Organ lain yang terkait dengan pengawasan adalah Dewan komisaris. Dimana dewan komisaris melakukan pengawasan secara umum kepada direksi. Dewan komisaris dalam melaksanakan tugasnya harus sesuai dengan prinsip-prinsip GCG yang sudah diatur dalam pedoman dan tata tertib yang sifatnya mengikat termasuk pelaksanaan ketentuan anggaran dasar dan keputusan RUPS dan peraturan perundang-undangan. Kegiatan lain mencakup pemberian saran kepada direksi berkaitan dengan pengurusan bank, penyusunan visi misi, serta rencana strategis bank lainnya. Pengkajian akan terus dilakukan dengan memeriksa laporanlaporan direksi dalam perkembangan bank baik itu informasi internal maupun informasi eksternal. Karena itu dewan komisaris melakukan rapat baik itu dengan jajaran komisaris maupun dengan direksi dengan menilai 
efektivitas pengendalian internal, menilai kompetensi, menelaah tugas dan wewenang independensi auditor intern berdasarkan standar pelaksaan audit intern dan auditor ekstern berdasarkan ruang lingkupnya. Dewan komisaris berhak meminta keterangan tentang perusahaan sehingga direksi harus transparan dalam menyampaikan informasi berkenaan dengan kondisi perusahaan. Juga sebagai pencegahan bahwa dewan komisaris harus tidak terpengaruh oleh berbagai pihak. Seperti tidak adanya hubunga afiliasi dari berbagai pihak. Dalam mengantisipasi adanya asimetri informasi ini, dibutuhkanlah pedoman yang mengatut bagaimana seharusnya masing-masing organ melakukan fungsi dan tanggung jawabnya dalam bentuk aturan-aturan GCG. Karena, dewan pada perusahaan ini memiliki kepentingan masing-masing. Pemegang saham menginginkan adanya return sedangkan manajer mempunyai kepentingannya tersendiri.

Berdasarkan penjelasan diatas, ada beberapa hipotesis yang diusulkan pada penelitian ini:

\section{Pertama}

Bank Syariah memiliki tingkat pengawasan yang lebih dari pada bank konvensional. Hal ini dibuktikan dengan adanya Dewan Pengawas Syariah yang tidak ada pada bank konvensional. Maka penerapan GCG yang juga sejalan dengan nilai-nilai syariah menjadi sebuah kebutuhan yang diharuskan ada pada bank syariah. Keunggulan ini sudah seharusnya membuat bank syariah memiliki peringkat yang tinggi dengan nilai 1 . Maka dihipotesiskan bahwa

H1 = Rata-rata, bank syariah memiliki nilai enerapan GCG yang tinggi

\section{Kedua}

Penerapan nilai-nilai GCG juga dipengaruhi oleh bagaimana kinerja Dewan Komisaris, Direksi, dan Dewan Pengawas Syariah. Karena masingmasing organ tersebut memiliki nilai tersendiri dalam penerapan GCG. 
Semakin baik nilai yang diberikan oleh para dewan, semakin baik pula nilai GCG pada sebuah bank. Maka dihipotesiskan bahwa

H2 = Penerapan GCG dipengaruhi oleh Dewan Komisaris, Direksi, dan Dewan Pengawas Syariah.

\section{METODE PENELITIAN}

\section{Pemilihan Sampel}

Populasi dari penelitian ini adalah bank-bank syariah ${ }^{2}$ yang terdaftar di OJK selama kurun waktu 2014-2018, keterbatasan penelitian karena beberapa bank tidak menyajikan laporan good corporate governance dengan lengkap, maka peneliti mengambil sampel sebanyak sembilan bank syariah di Indonesia

2. Metode Penelitian

Metode penelitian menggunakan uji ANOVA untuk melihat perbedaan rata-rata setiap kelompok. Karena peneliti ingin melihat bagaimana secara umum penerapan GCG pada perbankan syariah di Indonesia. Setelah megetahui hasil dari pengujian ANOVA, selanjutnya akan diuji dengan regresi data panel. Karena peneliti ingin melihat seberapa jauh pengaruh Dewan komisaris, Direksi, dan Dewan Pengawas syariah dalam pemenuhan prinsip-prinsip GCG, karena penilaian GCG pada bank itu sendiri juga termasuk penilaiannya terhadap organ-organ bank tersebut

\section{HASIL DAN PEMBAHASAN}

Peneliti ingin menguji apakah rata-rata nilai GCG untuk bank syariah adalah sebesar 1, dimana pengujian menggunakan one sample-t test.

${ }^{2}$ Masing-masing yaitu Bank BNI Syariah, Bank BRI Syariah, Bank Bukopin Syariah, Bank Syariah Mandiri, Bank Mega Syariah, Bank Muamalat, Bank Panin Syariah, Bank Victoria Syariah, dan Maybank Syariah (Sumber: Statistik Perbankan Syariah) 


\section{[Tabel 1]}

Dari pengujian diatas, didapatkan bahwa hipotesis rata-rata GCG bernilai $1^{3}$ ditolak dengan nilai probabilitas yang signifikan sebesar 0.0000 $(<0.05)$. Artinya, rata-rata bank syariah di Indonesia belum sepenuhnya mendapatkan nilai yang sangat bagus.

Pengujian selanjutnya peneliti ingin melihat bagaimana dengan nilai rata-rata GCG sebesar 2, dengan pengujian yang sama (one sample-t test).

\section{[Tabel 2]}

Didapatkan bahwa rata-rata nilai GCG bernilai 2 diterima dengan nilai probabilitas yang signifikan sebesar 0.5695 (>0.05). Artinya, rata-rata bank syariah di Indonesia masih bernilai 2 (Bagus) dalam mempraktikkan nilai GCG dalam operasinya.

Pengujian dilanjutkan dengan melihat bagaimana pengaruh Dewan Komisaris, Direksi, dan Dewan Pengawas Syariah pada penerapan GCG. Karena Dewan-dewan tersebut yang mempengaruhi hasil dari penilaian GCG. penilaian dalam indikator GCG itu sendiri terdapat penilaian terhadap masing-masing dewan dan direksi dalam perusahaan. Maka dilakukan pengujian regresi data panel.

\section{Pengujian dengan Common Effect Model (CEM)}

[Tabel 3]

Hasil regresi menunjukkan bahwa koefisien variabel DK dan D01 signifikan. Namun tanda koefisien variabel DK negatif, ini menunjukkan bahwa DK berpengaruh negatif terhadap GCG, perlu dilihat bagaimana kinerja dewan komisaris, bagaimana kehadiran rapatnya dan apakah dewan komisaris merangkap jabatan pada perusahaan lain atau tidak, karena hal tersebut akan mempengaruhi kinerja perusahaan.

\footnotetext{
${ }^{3}$ Nilai Komposit $<1,5=$ Sangat Baik, 1,5 $\leq$ Nilai Komposit $<2,5=$ Baik, 2,5 $\leq$ Nilai Komposit $<$ 3,5 = Cukup Baik, 3,5 $\leq$ Nilai Komposit $<4,5=$ Kurang Baik, 4,5 $\leq$ Nilai Komposit $<5=$ Tidak Baik (bersumber dari setiap laporan GCG perusahaan)
} 


\section{Analisis intersep antar perusahaan (The Fixed Effects Model/FEM)}

Diasumsikan bahwa setiap bank memiliki perbedaan, dimana perbedaan tersebut disebabkan oleh manajerial yang dilakukan, dimana dapat di rumuskan sebagai berikut

$$
\mathrm{GCG}_{\mathrm{it}}=\beta_{1 \mathrm{i}}+\beta_{2} \mathrm{DK}_{\mathrm{it}}+\beta_{3} \mathrm{D} 01_{\mathrm{it}}+\beta_{4} \mathrm{DPS}_{\mathrm{it}}+\mu_{\mathrm{it}}
$$

Pada persamaan diatas, subsscrip $i$ menunjukkan intersep untuk masing-masing bank berbeda, yang disebabkan oleh filosofi masing-masing bank. Pendekatan ini memasukkan "individualitas" perusahaan dengan membuat variasi intersep masing-masing perusahaan. Konstanta $\beta_{1 \mathrm{i}}$ bermakna intersep bervariasi terhadap individu perusahaan (i) tetapi tidak bervariasi terhadap waktu $(\mathrm{t})$.

Untuk membuat intersep dapat bervariasi pada setiap individu perusahaan, dapat dilakukan dengan variabel dummy dengan persamaan sebagai berikut

$$
\mathrm{GCG}_{i \mathrm{it}}=\mathrm{a}_{1}+\mathrm{a}_{2} \mathrm{D}_{2 \mathrm{i}}+\ldots \ldots+\mathrm{a}_{10} \mathrm{D}_{10 \mathrm{i}}+\beta_{2} \mathrm{DK}_{\mathrm{it}}+\beta_{3} \mathrm{D} 01_{\mathrm{it}}+\beta_{4} \mathrm{DPS} \mathrm{S}_{\mathrm{it}}+\mu_{\mathrm{it}}
$$

Diperoleh output sebagai berikut:

\section{[Tabel 4]}

dan pada persamaan selanjutnya didapatkan output yaitu:

[Tabel 5]

Dari hasil regersi fixed effect, memberikan hasil pada variabel DK dan D01 yang tidak signifikan. Artinya masing-masing DK dan D01 tidak memiliki perbedaan dalam manajemen dan kinerja yang diberikan. Sedangkan variabel DPS signifikan, artinya keputusan DPS dalam mengawasi bank berbeda pada masing-masing perusahaan.

Menarik dalam analisis fixed effect ini, karena didapatkan hasil bahwa baik itu direksi, maupun dewan komisaris (yang di proksikan dengan D01 dan DK) memiliki kesamaan dalam keputusan manajerial mereka. Beberapa pengaruh bisa dimungkinkan dalam hal ini, seperti rangkap 
jabatan antar perusahaan. namun disisi lain, DPS memiliki perbedaan pada masing-masing bank. Faktor-faktor lain dapat memungkinkan perbedaan DPS pada satu bank dengan bank yang lain. Seperti berapa jumlah hadir dalam setiap rapat, maupun kinerja DPS selama ini.

[Tabel 6]

\section{Analisis pengaruh waktu}

Analisis ini dilakukan untuk melihat pengaruh perusahaan yang setiap kinerjanya selalu mengalami perubahan dari waktu ke waktu. Berbagai faktor dapat mempengaruhi penilaian ini, seperti peraturan pemerintah, pajak, inflasi, bunga, dan permasalahan lainnya. Data diperoleh dari tahun 2014 sampai 2018, maka didapatkan 5 dummy dan dummy tahun 2014 (Dum14) sebagai pembanding atau excluded dummy. Adapun secara matematis, modelnya seperti dibawah ini

$\mathrm{GCG}_{\mathrm{it}}=\lambda_{0}+\lambda_{1} \operatorname{Dum} 14+\lambda_{2}$ Dum15 $+\ldots+\lambda_{5}$ Dum18 $+\beta_{2} \mathrm{DK}_{\mathrm{it}}+\beta_{3} \mathrm{D}_{\mathrm{it}}+$ $\beta_{5} \mathrm{DPS}_{\mathrm{it}}+\mu_{\mathrm{it}}$

Didapatkan otuputnya yaitu

[Tabel 7]

dari hasil regresi fixed effect untuk periode menunjukkan nilai $\mathrm{R}^{2}$ sebesar 0.286, sedangkan nilai $\mathrm{R}^{2}$ untuk pooled sebesar 0.232 , disini ada kenaikan sebesar 0.054. namun kenaikan nilai $\mathrm{R}^{2}$ ini tidak signifikan yang disebabkan oleh pengaruh waktu yang tidak signifikan. Jika diuji dengan redundant fixed effect test maka diperoleh hasil sebagai berikut:

[Tabel 8]

Model fixed effect tahun tidak lebih baik dibandingkan dengan pooled OLS dengan nilai $\mathrm{F}$ redundant test yang tidak signiffikan $(\mathrm{p}=0.6008)$. Dari hasil regresi dapat dilihat bahwa fungsi GCG tidak mengalami perubahan dari waktu ke waktu. Dan dari hasil tersebut diketahui bahwa pengaruh 
individu bank signifikan, akan tetapi pengaruh individu tahun tidak signifikan.

Dalam mengatasi permasalah tersebut, dimasukkan dummy waktu dan dummy individu secara bersama-sama dengan persamaan sebagai berikut:

$$
\begin{aligned}
& \mathrm{GCG}_{i t}=\mathrm{a}_{1}+\mathrm{a}_{2} \mathrm{D}_{\mathrm{BBSi}}+\mathrm{a}_{3} \mathrm{D}_{\mathrm{BMi}}+\mathrm{a}_{4} \mathrm{D}_{\mathrm{BMSi}}+\mathrm{a}_{5} \mathrm{D}_{\mathrm{BNISi}}+\mathrm{a}_{6} \mathrm{D}_{\mathrm{BPSi}}+\mathrm{a}_{7} \mathrm{D}_{\mathrm{BRISi}} \\
& +\mathrm{a}_{8} \mathrm{D}_{\mathrm{BSMi}}+\mathrm{a}_{9} \mathrm{D}_{\mathrm{BVSi}}+\mathrm{a}_{10} \mathrm{D}_{\mathrm{MSi}}+\lambda_{0}+\lambda_{1} \mathrm{Dum} 14+\lambda_{2} \mathrm{Dum}_{15}+\ldots . .+\lambda_{5} \mathrm{Dum} 18+ \\
& \beta_{2} \mathrm{DK}_{\mathrm{it}}+\beta_{3} \mathrm{D}_{01} 1_{\mathrm{it}}+\beta_{4} \mathrm{DPS}_{\mathrm{it}}+\mu_{\mathrm{it}}
\end{aligned}
$$

Dari regresi diatas, didapatkan output sebagai berikut:

\section{[Tabel 9]}

Hasil regresi fixed effect untuk periode menunjukkan bahwa variabel dummy tidak ada satupun yang signifikan secara statistik. Nilai $\mathrm{R}^{2}$ sebesar 0.7257, sedangkan nilai $\mathrm{R}^{2}$ untuk pooled sebesar 0.232 , dimana ada kenaikan sebesar 0.4937, namun kenaikan $\mathrm{R}^{2}$ ini tidak signifikan yang disebabkan oleh pengaruh dari tahun ke tahun tidak signifikan.

\section{Analisis Random Effect Model (REM)}

Permasalahan pada degree of freedom adalah memiliki banyak unit cross-sectional, yang akan mengarah pada multikolinieritas yang menyebabkan estimasi parameter menjadi menurun (Ghozali \& Ratmono, 2017). Maka model dalam REM ini adalah sebagai berikut:

$\mathrm{GCG}_{\mathrm{it}}=\beta_{1}+\beta_{2} \mathrm{DK}_{\mathrm{it}}+\beta_{3} \mathrm{D} 01_{\mathrm{it}}+\beta_{4} \mathrm{DPS}_{\mathrm{it}}+\mathrm{w}_{\mathrm{it}}$

Dimana $\mathrm{w}_{\mathrm{it}}=\varepsilon_{\mathrm{i}}+\mathrm{u}_{\mathrm{it}}$

Didapatkan hasil pengujian sebagai berikut:

\section{[Tabel 10]}

dari hasil REM, dapat disimpulkan bahwa hasil estimasi tidak berbeda jauh dengan FEM untuk nilai koefisien dan signifikansinya, maka dalam memilih antara pengujian FEM dan REM dilakukan uji hausman. Dan hasil dari pengujian hausman adalah 


\section{[Tabel 11]}

Dari output diatas menunjukkan bahwa hasil uji hasuman signifikan dengan chi-square sebesar 12.663 dan nilai p sebesar 0.005. Maka dapat disimpulkan bahwa kita menggunakan model FEM. Namun dari hasil cross-section random effect test comparisons terlihat bahwa DK dan D01 tidak berbeda signifikan antara FEM dan REM

\section{E. PENUTUP}

Dari hasil pengujian didapati bahwa rata-rata bank syariah memiliki peringkat yang 'bagus' dibuktikan dengan hasil analisis bahwa ketika diberikan dengan nilai 1, hasil yang didapat tidak signifikan, berbeda halnya ketika diberi nilai 2, didapatkan hasil yang signifikan. Temuan ini memberikan pandangan bahwa rata-rata penerapan GCG pada bank syariah mendapatkan nilai yang 'bagus' bukan 'sangat bagus'. Selanjutnya setelah didapatkan hasil uji rata-rata, peneliti ingin melihat sejauh apa pengaruh Dewan komisaris, Direksi, dan Dewan Pengawas Syariah. Dari hasil uji analisis Data Panel dalam analsis secara umum (CEM) bahwa Dewan komisaris dan Direksi mendapatkan hasil yang signifikan, sedangkan Dewan Pengawas Syariah tidak mendapatkan nilai yang signifikan. Menarik bahwa pada bank syariah justru Dewan Pengawas Syariah itu sendiri yang tidak berpengaruh dalam penerapan GCG. Beberapa hal dapat melatarbelakangi ketidaksignifikan hasil ini. Seperti apakah Dewan Pengawas Syariah itu sendiri merangkap jabatan pada perusahaan lain, sehingga mempengaruhi hasil keputusan yang dibuat, seberapa banyak kehadiran Dewan Pengawas Syariah dalam kegiatan rapat baik itu sesama dewan ataupun dengan organ lainnya. Dalam analisis fixed effect, didapati bahwa Dewan Komisaris dan Dewan Direksi memiliki kesamaan dalam kinerja pada masing-masing bank. Menariknya pada Dewan Pengawas Syariah memiliki perbedaan dalam kinerja pada setiap 
Zul Ihsan Mu'arrif

bank. Dari hasil regresi analisis waktu didapati bahwa fungsi GCG tidak mengalami perubahan dari waktu ke waktu. Dan dari hasil tersebut diketahui bahwa pengaruh individu bank signifikan, akan tetapi pengaruh individu tahun tidak signifikan. 


\section{DAFTAR PUSTAKA}

Abdul-Majid, M., Falahaty, M., \& Jusoh, M. (2017). Performance of Islamic and conventional banks: A meta-frontier approach. Research in International Business and Finance, 42, 1327-1335. https://doi.org/10.1016/j.ribaf.2017.07.069

Alandejani, M., Kutan, A. M., \& Samargandi, N. (2017). Do Islamic banks fail more than conventional banks? Journal of International Financial Markets, Institutions and Money, 50, 135-155. https://doi.org/10.1016/j.intfin.2017.05.007

Alexakis, C., Izzeldin, M., Johnes, J., \& Pappas, V. (2019). Performance and productivity in Islamic and conventional banks: Evidence from the global financial crisis. Economic Modelling, 79, 1-14. https://doi.org/10.1016/j.econmod.2018.09.030

Ali, S., Liu, B., \& Su, J. J. (2018). Does corporate governance quality affect default risk? The role of growth opportunities and stock liquidity. International Review of Economics $\mathcal{E}$ Finance, 58, 422-448. https:// doi.org/10.1016/j.iref.2018.05.003

Alijoyo, A., \& Zaini, S. (2004). Komisaris Independen: Penggerak Prakik GCG di Perusahaan. Jakarta: Indeks.

Alqahtani, F., \& Mayes, D. G. (2018). Financial stability of Islamic banking and the global financial crisis: Evidence from the Gulf Cooperation Council. Economic Systems, 42(2), 346-360. https://doi.org/10.1016/j.ecosys.2017.09.001

Alqahtani, F., Mayes, D. G., \& Brown, K. (2017a). Islamic bank efficiency compared to conventional banks during the global crisis in the GCC region. Journal of International Financial Markets, Institutions and Money, 51, 58-74. https:/ / doi.org/10.1016/j.intfin.2017.08.010

Alqahtani, F., Mayes, D. G., \& Brown, K. (2017b). Reprint of Economic turmoil and Islamic banking: Evidence from the Gulf Cooperation Council. PacificBasin Finance Journal, 42, 113-125. https://doi.org/10.1016/j.pacfin.2016.06.013

Asmild, M., Kronborg, D., Mahbub, T., \& Matthews, K. (2018). The efficiency patterns of Islamic banks during the global financial crisis: The case of 
Bangladesh. The Quarterly Review of Economics and Finance. https://doi.org/10.1016/j.qref.2018.04.004

Athari, S. A., Adaoglu, C., \& Bektas, E. (2016). Investor protection and dividend policy: The case of Islamic and conventional banks. Emerging Markets Review, 27, 100-117. https://doi.org/10.1016/j.ememar.2016.04.001

Ben Slimane, F., \& Padilla Angulo, L. (2018). Strategic change and corporate governance: Evidence from the stock exchange industry. Journal of Business Research. https://doi.org/10.1016/j.jbusres.2018.10.045

Connelly, J. T., Limpaphayom, P., Nguyen, H. T., \& Tran, T. D. (2017). A tale of two cities: Economic development, corporate governance and firm value in Vietnam. Research in International Business and Finance, 42, 102-123. https://doi.org/10.1016/j.ribaf.2017.04.002

Ducassy, I., \& Montandrau, S. (2015). Corporate social performance, ownership structure, and corporate governance in France. Research in International Business and Finance, 34, 383-396. https://doi.org/10.1016/j.ribaf.2015.02.002

Effendi, Muh. A. (2016). The Power of Good Corporate Governance: Teori dan Implementasi. Jakarta: Salemba Empat.

Fakhfekh, M., Hachicha, N., Jawadi, F., Selmi, N., \& Idi Cheffou, A. (2016). Measuring volatility persistence for conventional and Islamic banks: An FI-EGARCH approach. Emerging Markets Review, 27, 84-99. https://doi.org/10.1016/j.ememar.2016.03.004

Ghozali, I., \& Ratmono, D. (2017). Analisis Multivariat dan Ekonometrika: Teori, Konsep, dan Aplikasi dengan Eviews 10. Semarang: Badan Penerbit Universitas Diponegoro.

Habib, A., \& Hasan, M. M. (2019). Corporate life cycle research in accounting, finance and corporate governance: A survey, and directions for future research. International Review of Financial Analysis, 61, 188-201. https://doi.org/10.1016/j.irfa.2018.12.004

Hassan, M. K., Khan, A., \& Paltrinieri, A. (2019). Liquidity risk, credit risk and stability in Islamic and conventional banks. Research in International Business and Finance, 48, 17-31. https:/ / doi.org/10.1016/j.ribaf.2018.10.006

Ibrahim, M. H., \& Rizvi, S. A. R. (2018). Bank lending, deposits and risk-taking in times of crisis: A panel analysis of Islamic and conventional banks. 
Emerging Markets Review, 35, 31-47. https://doi.org/10.1016/j.ememar.2017.12.003

Iqbal, J., Strobl, S., \& Vähämaa, S. (2015). Corporate governance and the systemic risk of financial institutions. Journal of Economics and Business, 82, 42-61. https://doi.org/10.1016/j.jeconbus.2015.06.001

Li, C., Li, J., Liu, M., Wang, Y., \& Wu, Z. (2017). Anti-misconduct policies, corporate governance and capital market responses: International evidence. Journal of International Financial Markets, Institutions and Money, 48, 47-60. https://doi.org/10.1016/j.intfin.2016.12.002

Miah, M. D., \& Uddin, H. (2017). Efficiency and stability: A comparative study between islamic and conventional banks in GCC countries. Future Business Journal, 3(2), 172-185. https:/ / doi.org/10.1016/j.fbj.2017.11.001

Nazir, M. S., \& Afza, T. (2018). Does managerial behavior of managing earnings mitigate the relationship between corporate governance and firm value? Evidence from an emerging market. Future Business Journal, 4(1), 139-156. https://doi.org/10.1016/j.fbj.2018.03.001

Neifar, S., \& Jarboui, A. (2018). Corporate governance and operational risk voluntary disclosure: Evidence from Islamic banks. Research in International Business and Finance, 46, 43-54. https://doi.org/10.1016/j.ribaf.2017.09.006

Olson, D., \& Zoubi, T. (2017). Convergence in bank performance for commercial and Islamic banks during and after the Global Financial Crisis. The Quarterly Review of Economics and Finance, 65, 71-87. https:/ / doi.org/10.1016/j.qref.2016.06.013

Patel, P. C., Guedes, M. J., Soares, N., \& da Conceição Gonçalves, V. (2018). Strength of the association between $R \& D$ volatility and firm growth: The roles of corporate governance and tangible asset volatility. Journal of Business Research, 88, 282-288. https://doi.org/10.1016/j.jbusres.2017.12.033

Pillai, R., \& Al-Malkawi, H.-A. N. (2018). On the relationship between corporate governance and firm performance: Evidence from GCC countries. Research in International Business and Finance, 44, 394-410. https://doi.org/10.1016/j.ribaf.2017.07.110 
Ramlan, H., \& Adnan, M. S. (2016). The Profitability of Islamic and Conventional Bank: Case Study in Malaysia. Procedia Economics and Finance, 35, 359-367. https://doi.org/10.1016/S2212-5671(16)00044-7

Shahid, M. S., \& Abbas, M. (2019). Does corporate governance play any role in investor confidence, corporate investment decisions relationship? Evidence from Pakistan and India. Journal of Economics and Business. https://doi.org/10.1016/j.jeconbus.2019.03.003

Surya, I., \& Yustiavanda, I. (2006). Penerapan Good Corporate Governance: Mengesampingkan Hak-hak Istimewa Demi Kelangsungan Usaha. Jakarta: Kencana.

www.bankmuamalat.co.id

www.bankvictoriasyariah.co.id

www.brisyariah.co.id

www.bnisyariah.co.id

www.syariahmandiri.co.id

www.megasyariah.co.id/

www.paninbanksyariah.co.id

www.syariahbukopin.co.id/id

www.maybank.co.id

Yu, Z., Li, J., \& Yang, J. (2017). Does corporate governance matter in competitive industries? Evidence from China. Pacific-Basin Finance Journal, 43, 238-255. https://doi.org/10.1016/j.pacfin.2017.04.008 


\section{LAMPIRAN TABEL}

\section{Tabel 1}

\begin{tabular}{|c|c|c|}
\hline \multicolumn{3}{|c|}{ Hypothesis Testing for GCG } \\
\hline \multicolumn{3}{|c|}{ Sample: 20142018} \\
\hline \multicolumn{3}{|c|}{ Included observations: 45} \\
\hline \multicolumn{3}{|c|}{ Test of Hypothesis: Mean $=1.000000$} \\
\hline \multicolumn{3}{|c|}{ Sample Mean $=2.044444$} \\
\hline \multicolumn{3}{|c|}{ Sample Std. Dev. $=0.520295$} \\
\hline Method & $\underline{\text { Value }}$ & $\underline{\text { Probability }}$ \\
\hline t-statistic & 13.46610 & 0.0000 \\
\hline
\end{tabular}

Tabel 2

\begin{tabular}{|c|c|c|}
\hline \multicolumn{3}{|c|}{ Hypothesis Testing for GCG } \\
\hline \multicolumn{3}{|c|}{ Sample: 20142018} \\
\hline \multicolumn{3}{|c|}{ Included observations: 45} \\
\hline \multicolumn{3}{|c|}{ Test of Hypothesis: Mean $=2.000000$} \\
\hline \multicolumn{3}{|c|}{ Sample Mean $=2.044444$} \\
\hline \multicolumn{3}{|c|}{ Sample Std. Dev. $=0.520295$} \\
\hline \multirow[t]{2}{*}{ Method } & Value & Probability \\
\hline & 0.573 & \\
\hline t-statistic & 025 & 0.5695 \\
\hline
\end{tabular}


[Tabel 3] Tabel 3

\begin{tabular}{|c|c|c|c|c|}
\hline \multicolumn{5}{|c|}{$\begin{array}{l}\text { Dependent Variable: GCG? } \\
\text { Method: Pooled Least Squares } \\
\text { Sample: } 15 \\
\text { Included observations: } 5 \\
\text { Cross-sections included: } 9 \\
\text { Total pool (balanced) observations: } 45\end{array}$} \\
\hline Variable & $\begin{array}{r}\text { Coef } \\
\text { ficient }\end{array}$ & $\begin{array}{l}\text { Std. } \\
\text { Error }\end{array}$ & Statistic & Prob. \\
\hline C & $\begin{array}{r}93.15 \\
953 \\
-\end{array}$ & $\begin{array}{r}9.8 \\
06625 \\
2.3\end{array}$ & $\begin{array}{r}9.49965 \\
3 \\
-\end{array}$ & 0.0000 \\
\hline DK? & $\begin{array}{r}7.556032 \\
5.390\end{array}$ & $\begin{array}{r}99195 \\
1.7\end{array}$ & $\begin{array}{r}3.149403 \\
3.08458\end{array}$ & 0.0031 \\
\hline D01? & $\begin{array}{r}488 \\
-\end{array}$ & $\begin{array}{r}47555 \\
4.3\end{array}$ & 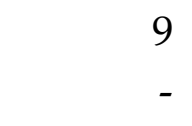 & 0.0036 \\
\hline DPS? & 5.724194 & 55069 & 1.314375 & 0.1960 \\
\hline R- & 0.232 & $\mathrm{Me}$ & endent & 73.888 \\
\hline squared & 540 & var & & 89 \\
\hline Adjusted & 0.176 & S.D & ndent & 13.007 \\
\hline R-squared & 385 & var & & 38 \\
\hline S.E. of & 11.80 & $\mathrm{Ak}$ & & 7.8595 \\
\hline regression & 462 & criterion & & 46 \\
\hline Sum & 5713. & & & 8.0201 \\
\hline squared resid & 310 & Sch & criterion & 38 \\
\hline $\log$ & - & $\mathrm{Ha}$ & Quinn & 7.9194 \\
\hline likelihood & 172.8398 & criter. & & 13 \\
\hline F- & 4.141 & $\mathrm{Du}$ & Jatson & 1.2343 \\
\hline statistic & 004 & stat & & 95 \\
\hline Prob(F- & 0.011 & & & \\
\hline statistic) & 837 & & & \\
\hline
\end{tabular}


Tabel 4

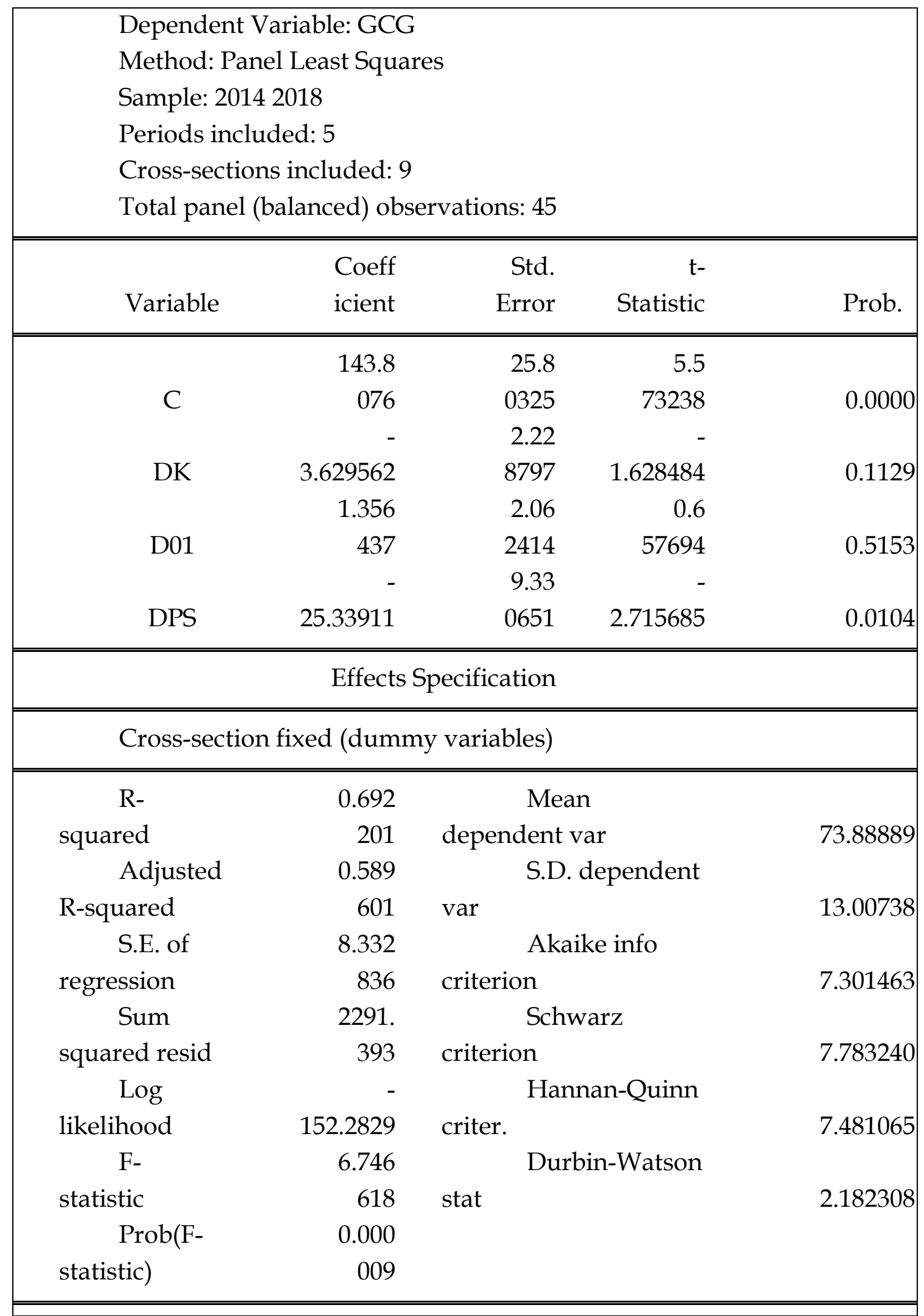


Tabel 5

\begin{tabular}{|c|c|c|c|c|}
\hline \multicolumn{5}{|c|}{$\begin{array}{l}\text { Dependent Variable: GCG? } \\
\text { Method: Pooled Least Squares } \\
\text { Sample: } 15 \\
\text { Included observations: } 5 \\
\text { Cross-sections included: } 9 \\
\text { Total pool (balanced) observations: } 45\end{array}$} \\
\hline Variable & $\begin{array}{r}\text { Coeffi } \\
\text { cient }\end{array}$ & $\begin{array}{r}\text { Std } \\
\text {. Error }\end{array}$ & Statistic & Prob. \\
\hline C & $\begin{array}{r}143.80 \\
76 \\
-\end{array}$ & $\begin{array}{r}25 . \\
80325 \\
2.2\end{array}$ & $\begin{array}{r}5.5 \\
73238 \\
-\end{array}$ & 0.0000 \\
\hline DK? & $\begin{array}{r}3.629562 \\
1.3564\end{array}$ & $\begin{array}{r}28797 \\
2.0\end{array}$ & $\begin{array}{r}1.628484 \\
0.6\end{array}$ & 0.1129 \\
\hline D01? & $\begin{array}{r}37 \\
-\end{array}$ & $\begin{array}{r}62414 \\
9.3\end{array}$ & $\begin{array}{r}57694 \\
-\end{array}$ & 0.5153 \\
\hline $\begin{array}{c}\text { DPS? } \\
\text { Fixed } \\
\text { Effects (Cross) }\end{array}$ & 25.33911 & 30651 & 2.715685 & 0.0104 \\
\hline BBS--C & 9.762842 & & & \\
\hline BM--C & $\begin{array}{r}- \\
6.695983 \\
13.689\end{array}$ & & & \\
\hline BMS--C & $\begin{array}{r}94 \\
-\end{array}$ & & & \\
\hline BNIS--C & 10.03413 & & & \\
\hline BPS--C & $\begin{array}{r}10.21747 \\
-\end{array}$ & & & \\
\hline BRIS--C & $\begin{array}{r}7.944342 \\
29.227\end{array}$ & & & \\
\hline BSM--C & $\begin{array}{r}27 \\
-\end{array}$ & & & \\
\hline BVS--C & 16.39800 & & & \\
\hline
\end{tabular}


18.135

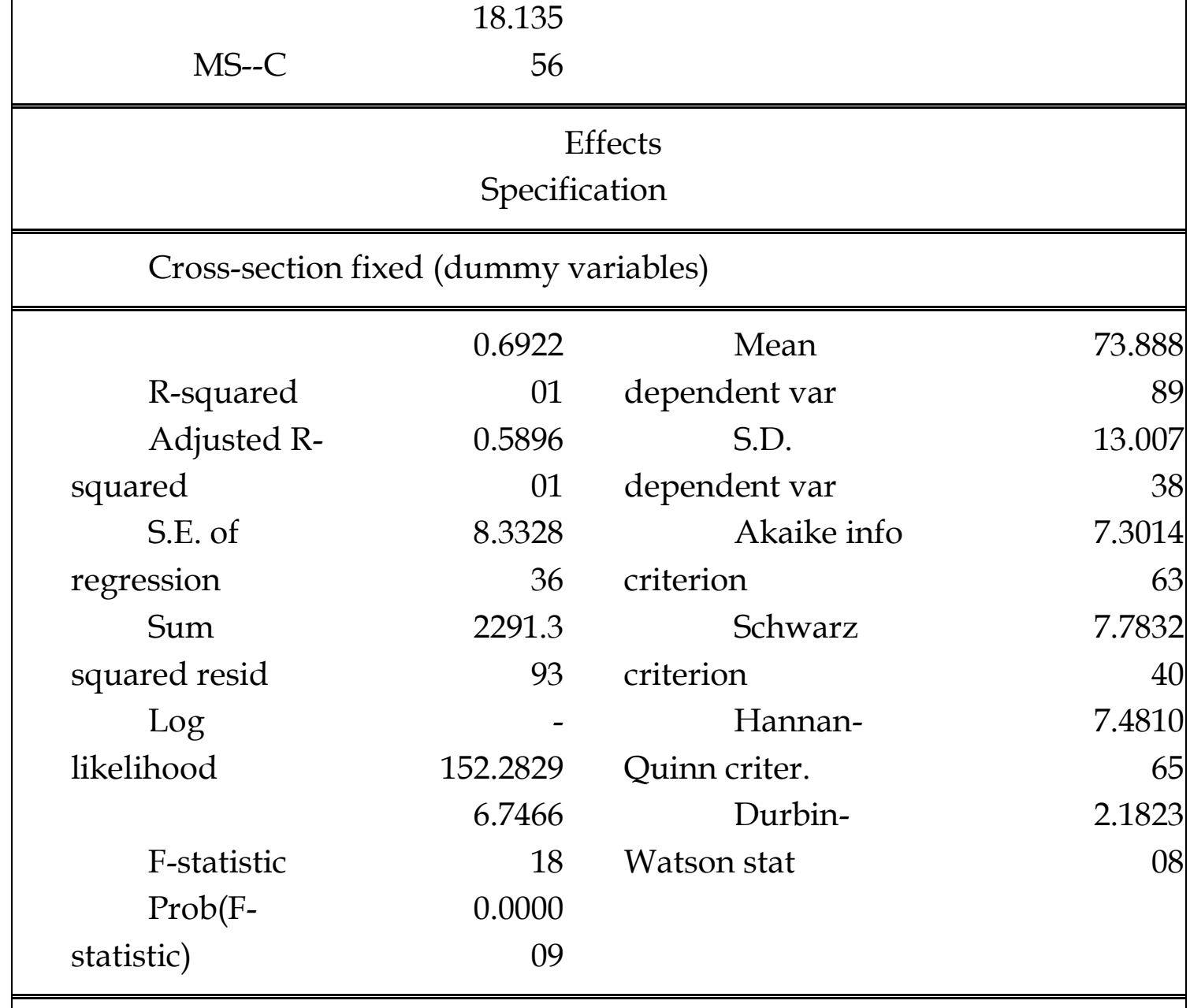

Tabel 6

\begin{tabular}{|c|c|c|c|}
\hline \multicolumn{4}{|c|}{$\begin{array}{l}\text { Redundant Fixed Effects Tests } \\
\text { Pool: BANK } \\
\text { Test cross-section fixed effects }\end{array}$} \\
\hline Effects Test & $\begin{array}{l}\text { Stat } \\
\text { istic }\end{array}$ & d.f. & Prob. \\
\hline & 6.16 & $(8,3$ & \\
\hline Cross-section F & 0185 & 3) & 0.0001 \\
\hline Cross-section Chi- & 41.1 & & \\
\hline square & 13733 & 8 & 0.0000 \\
\hline
\end{tabular}


Method: Panel Least Squares

Date: 05/14/19 Time: 13:34

Sample: 15

Included observations: 5

Cross-sections included: 9

Total pool (balanced) observations: 45

\begin{tabular}{|c|c|c|c|c|}
\hline Variable & $\begin{array}{r}\text { Coe } \\
\text { fficient }\end{array}$ & $\begin{array}{l}\text { Std. } \\
\text { Error }\end{array}$ & Statistic & Prob. \\
\hline & 93.1 & 9.80 & 9.4 & \\
\hline \multirow[t]{2}{*}{$\mathrm{C}$} & 5953 & 6625 & 99653 & 0.0000 \\
\hline & - & 2.39 & - & \\
\hline \multirow[t]{2}{*}{ DK? } & 7.556032 & 9195 & 3.149403 & 0.0031 \\
\hline & 5.39 & 1.74 & 3.0 & \\
\hline \multirow[t]{2}{*}{ D01? } & 0488 & 7555 & 84589 & 0.0036 \\
\hline & - & 4.35 & - & \\
\hline DPS? & 5.724194 & 5069 & 1.314375 & 0.1960 \\
\hline R- & 0.23 & \multicolumn{2}{|c|}{ Mean } & \\
\hline squared & 2540 & \multicolumn{2}{|c|}{ dependent var } & 73.88889 \\
\hline Adjusted & 0.17 & \multicolumn{2}{|c|}{ S.D. dependent } & \\
\hline R-squared & 6385 & var & & 13.00738 \\
\hline S.E. of & 11.8 & \multicolumn{2}{|c|}{ Akaike info } & \\
\hline regression & 0462 & criterion & & 7.859546 \\
\hline Sum & 571 & \multicolumn{2}{|c|}{ Schwarz } & \\
\hline squared resid & 3.310 & criterion & & 8.020138 \\
\hline $\log$ & - & \multirow{2}{*}{\multicolumn{2}{|c|}{ Hannan-Quinn }} & \\
\hline likelihood & 172.8398 & & & 7.919413 \\
\hline & 4.14 & \multicolumn{2}{|c|}{ Durbin- } & \\
\hline F-statistic & 1004 & \multirow{3}{*}{\multicolumn{2}{|c|}{ Watson stat }} & 1.234395 \\
\hline Prob(F- & 0.01 & & & \\
\hline statistic) & 1837 & & & \\
\hline
\end{tabular}


Tabel 7

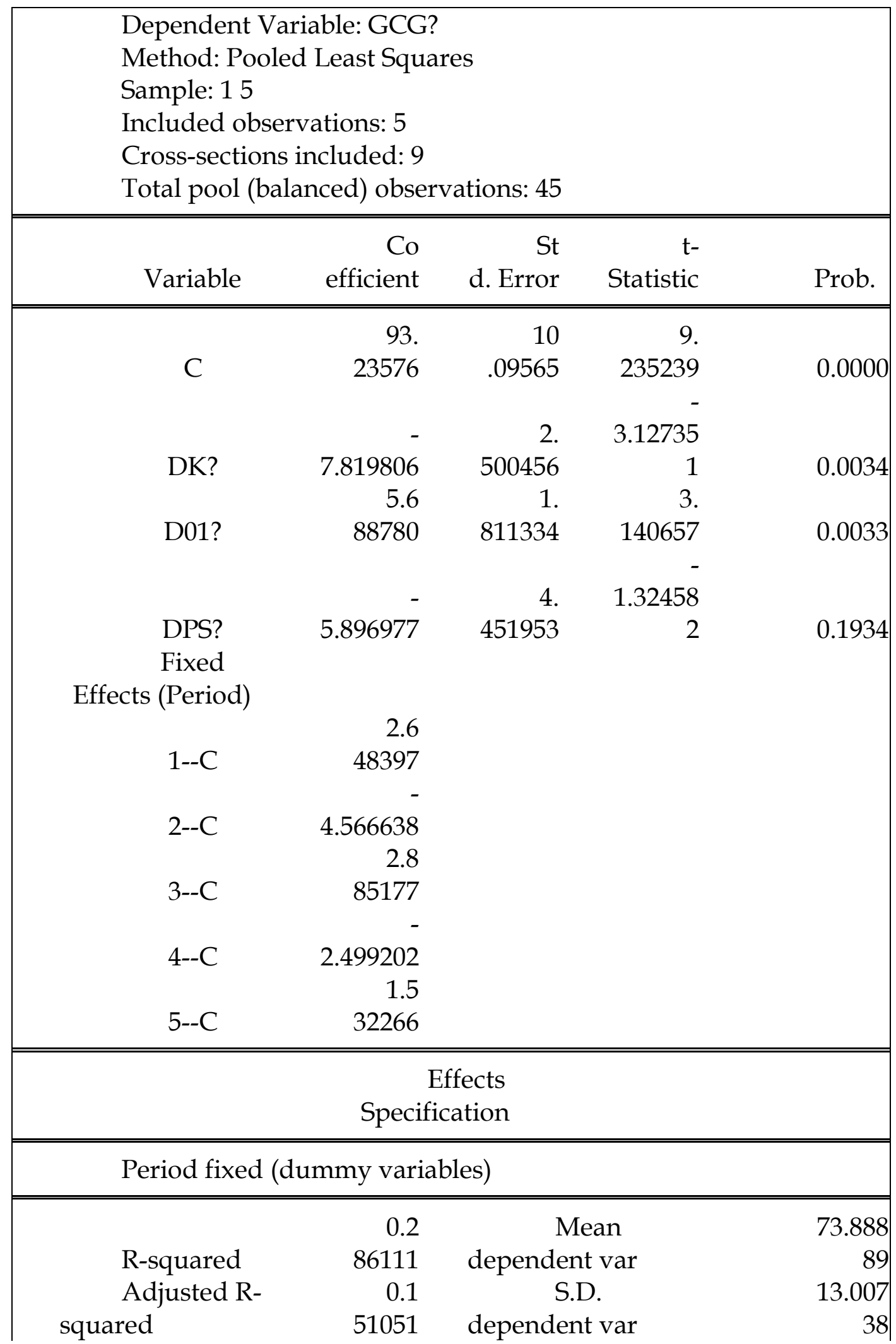


S.E. of

regression

Sum

squared resid

Log

likelihood

F-statistic

Prob(F-
11. Akaike info

98480 criterion

531

4.507

Schwarz

criterion

Hannan-

171.2117 Quinn criter.

2.1 Durbin-

18397 Watson stat

0.0

Tabel 8

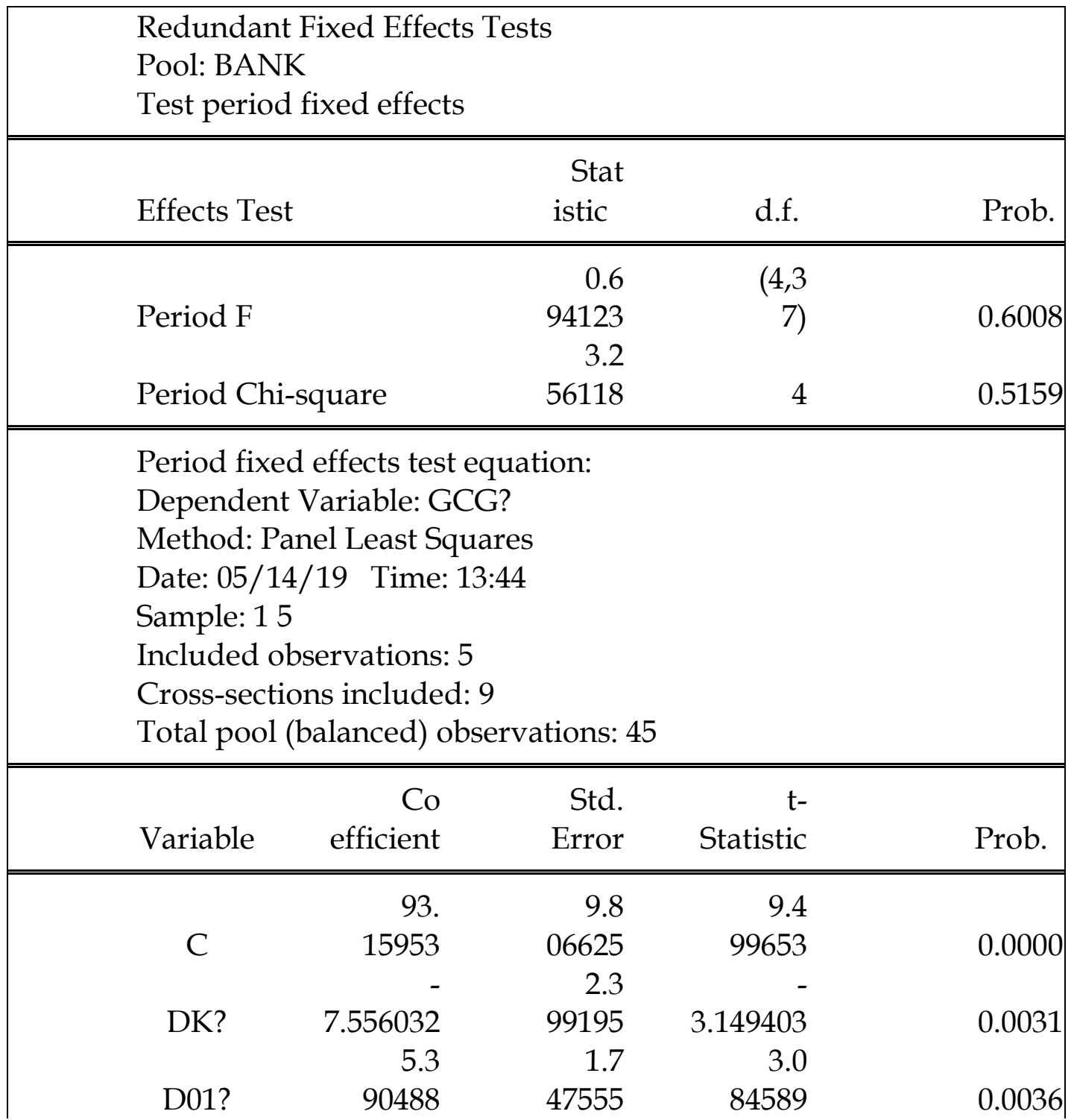




\begin{tabular}{|c|c|c|c|}
\hline DPS? & 5.724194 & $\begin{array}{r}4.3 \\
55069\end{array}$ & 0.1960 \\
\hline R- & 0.2 & Mean & \\
\hline squared & 32540 & dependent var & 73.88889 \\
\hline Adjuste & 0.1 & S.D. & \\
\hline d R-squared & 76385 & dependent var & 13.00738 \\
\hline S.E. of & 11. & Akaike info & \\
\hline regression & 80462 & criterion & 7.859546 \\
\hline Sum & 571 & Schwarz & \\
\hline squared resid & 3.310 & criterion & 8.020138 \\
\hline $\log$ & - & Hannan- & \\
\hline likelihood & 172.8398 & Quinn criter. & 7.919413 \\
\hline F- & 4.1 & Durbin- & \\
\hline statistic & 41004 & Watson stat & 1.234395 \\
\hline Prob(F- & 0.0 & & \\
\hline statistic) & 11837 & & \\
\hline
\end{tabular}

Tabel 9

\begin{tabular}{|c|c|c|c|c|}
\hline \multicolumn{5}{|c|}{$\begin{array}{l}\text { Dependent Variable: GCG? } \\
\text { Method: Pooled Least Squares } \\
\text { Sample: } 15 \\
\text { Included observations: } 5 \\
\text { Cross-sections included: } 9 \\
\text { Total pool (balanced) observations: } 45\end{array}$} \\
\hline Variable & $\begin{array}{r}\text { Co } \\
\text { efficient }\end{array}$ & d. Error & Statistic & Prob. \\
\hline $\mathrm{C}$ & $\begin{array}{r}13 \\
7.5957\end{array}$ & $\begin{array}{r}28 \\
.44540\end{array}$ & $\begin{array}{r}4 . \\
837187 \\
-\end{array}$ & $\begin{array}{r}0.000 \\
0\end{array}$ \\
\hline DK? & $\begin{array}{r}- \\
3.602852\end{array}$ & $\begin{array}{r}2 . \\
379809\end{array}$ & $\begin{array}{r}1.51392 \\
5\end{array}$ & $\begin{array}{r}0.140 \\
9\end{array}$ \\
\hline D01? & $\begin{array}{r}2.1 \\
93681\end{array}$ & $\begin{array}{r}2 . \\
142250\end{array}$ & $\begin{array}{r}1 . \\
024008\end{array}$ & $\begin{array}{r}0.314 \\
3\end{array}$ \\
\hline $\begin{array}{l}\text { DPS? } \\
\text { Fixed Effects } \\
\text { (Cross) } \\
\text { BBS--C }\end{array}$ & 24.48719 & $\begin{array}{r}10 \\
.00156\end{array}$ & $\begin{array}{r}- \\
2.44833 \\
8\end{array}$ & $\begin{array}{r}0.020 \\
6\end{array}$ \\
\hline
\end{tabular}




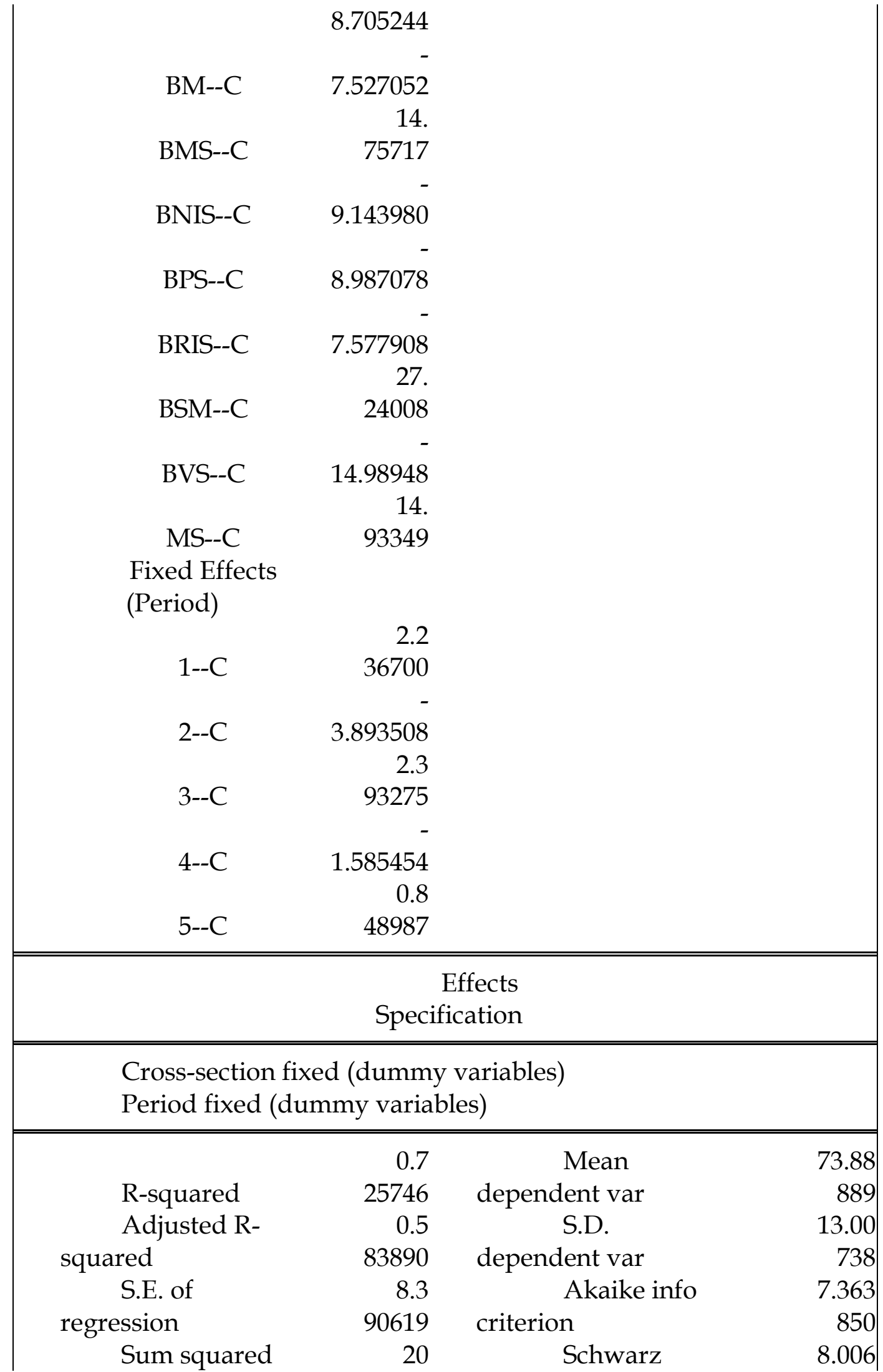




\begin{tabular}{|crlr|} 
resid & 41.672 & criterion & 219 \\
Log & - & Hannan- & 7.603 \\
likelihood & 149.6866 & Quinn criter. & 319 \\
& 5.1 & Durbin- & 1.932 \\
F-statistic & 16081 & Watson stat & 311 \\
Prob(F- & 0.0 & & \\
statistic) & 00085 & & \\
\hline \hline
\end{tabular}

Tabel 10

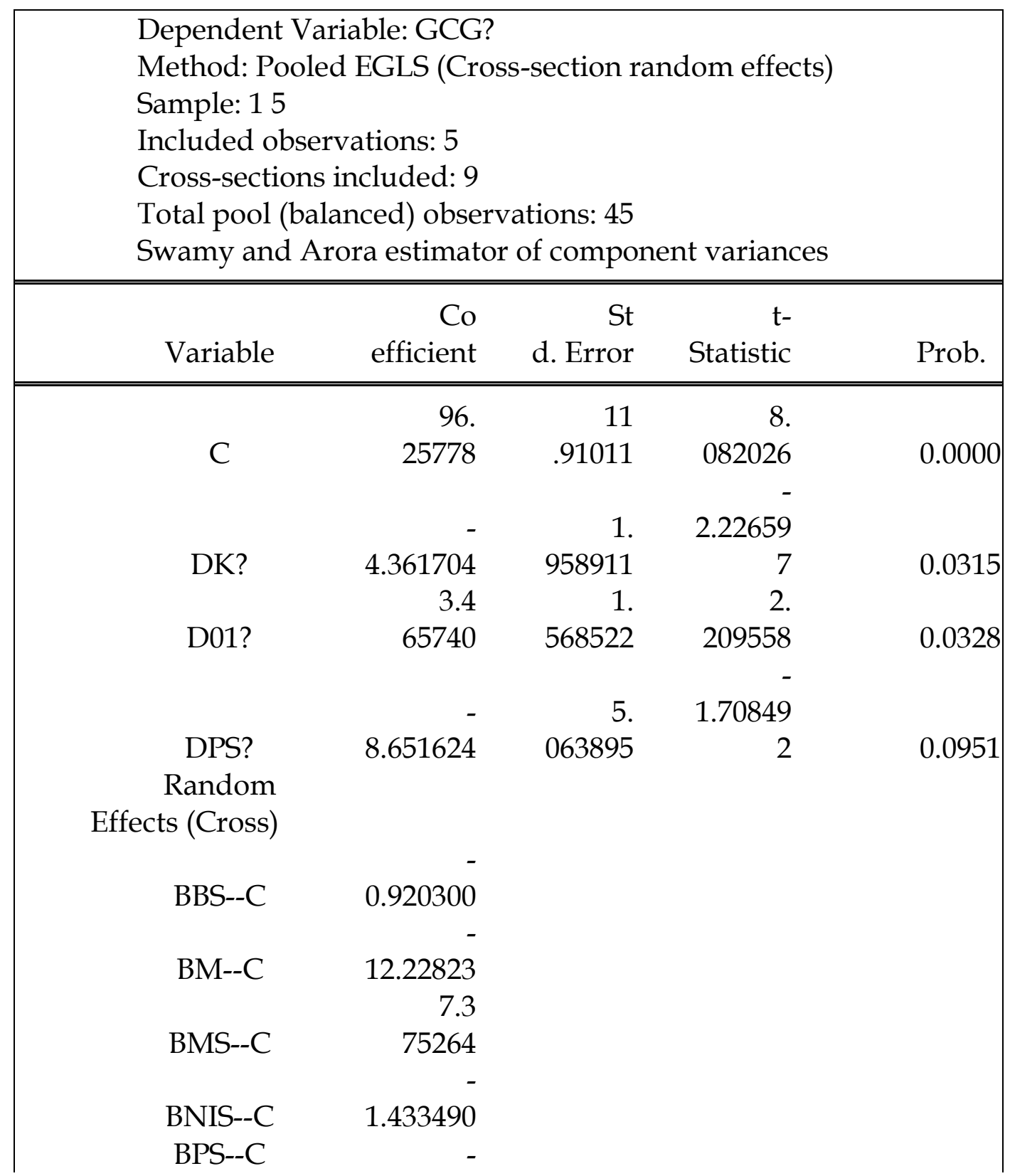




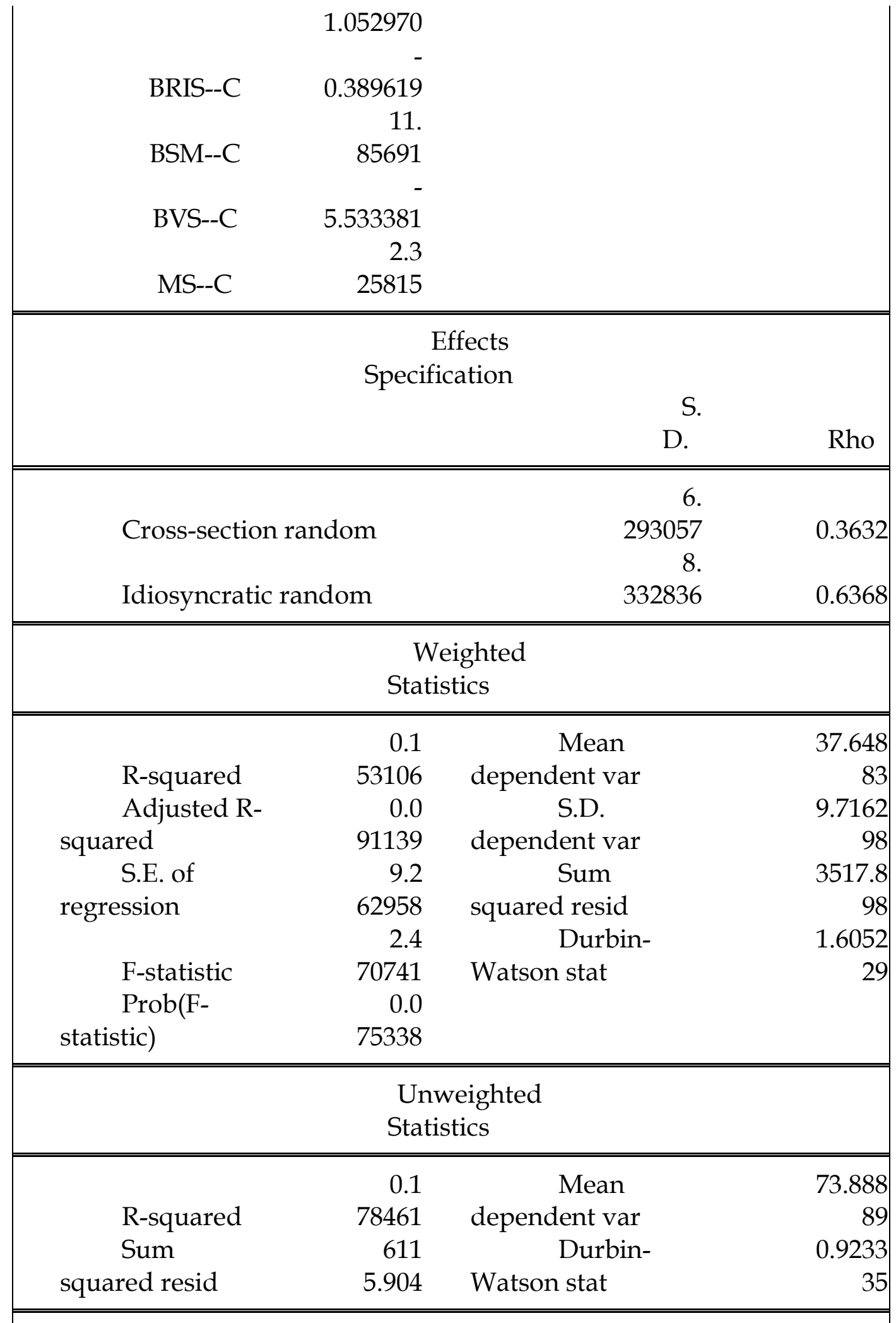


Tabel 11

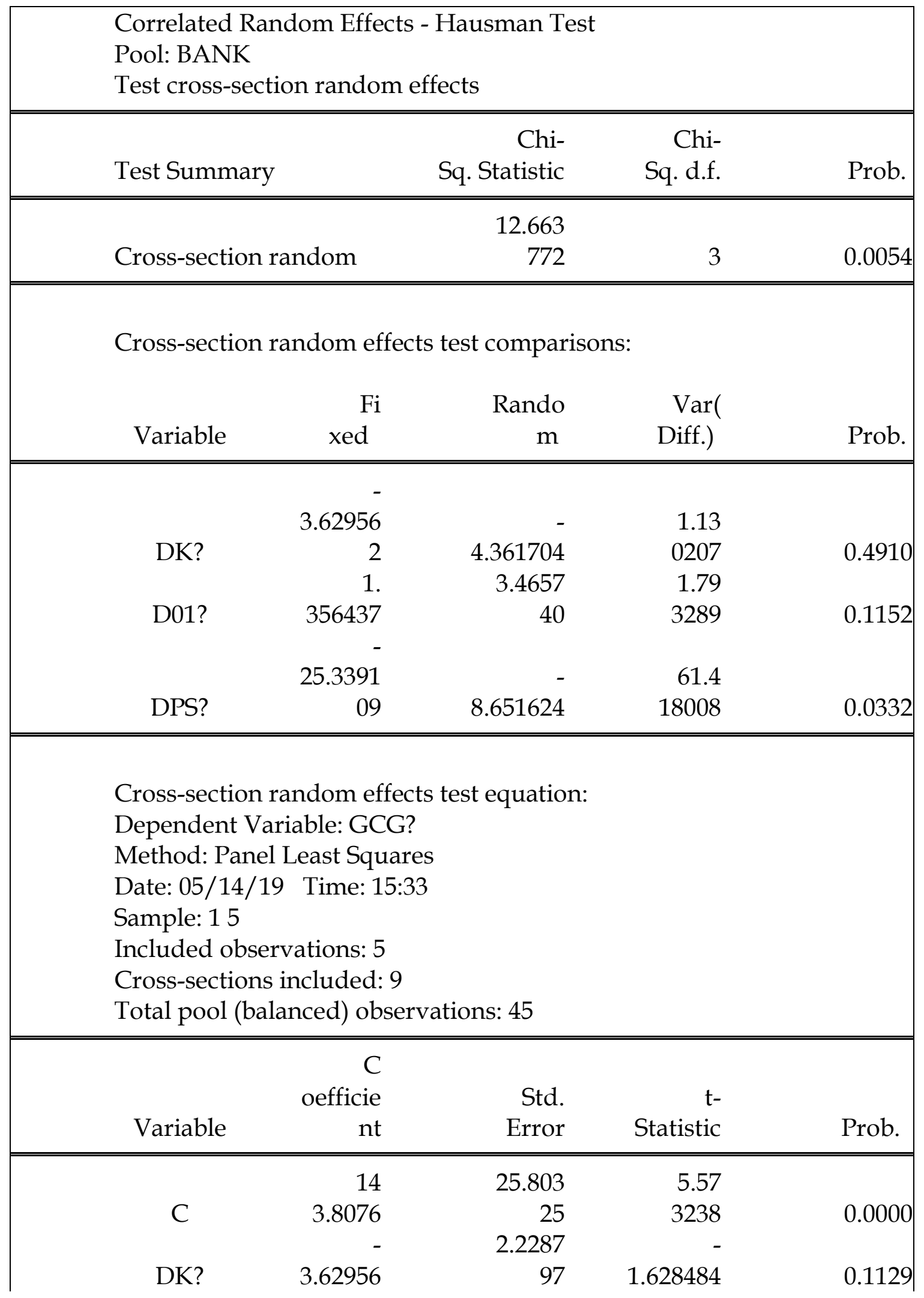




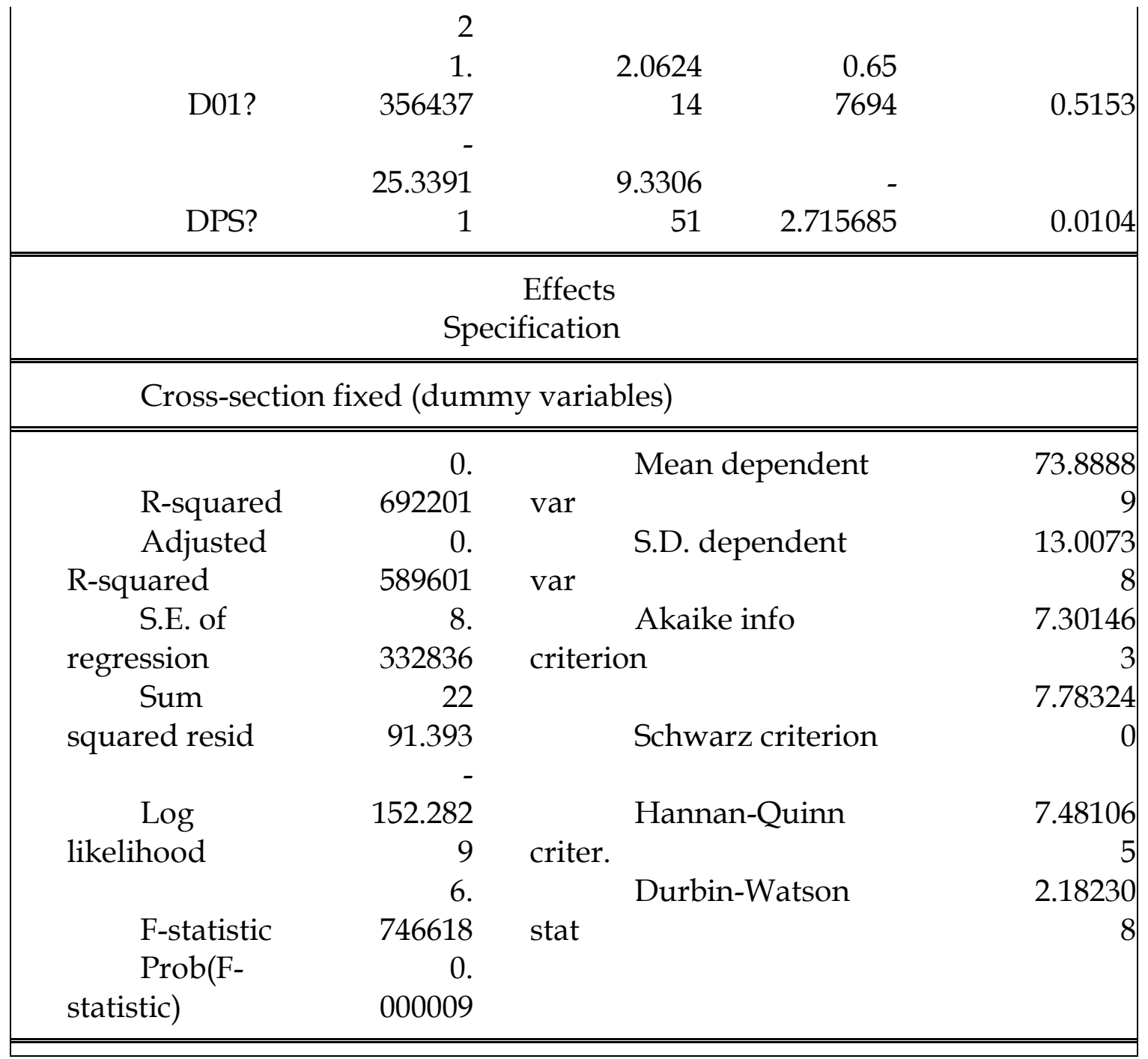

